\title{
The Tangled Chain
}





\section{RUTH A. FOX}

\section{The Tangled Chain}

\section{The Structure of Disorder in the Anatomy of Melancholy}

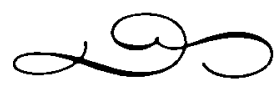

University of California Press

Berkeley, Los Angeles, London 
University of California Press

Berkeley and Los Angeles, Califormia

University of California Press, Ltd.

London, England

Copyright (C) 1976, by

The Regents of the University of California

ISBN 0-520-03085-0

Library of Congress Catalog Card Number: 75-17296

Printed in the United States of America 
For my family 
His speech was like a tangled chain; nothing impaired, but all disordered.

- Shakespeare, A Midsummer-Night's Dream

And this is that Homer's golden chain, which reacheth down from heaven to earth, by which every creature is annexed, and depends on his Creator.

-BurTon, The Anatomy of Melancholy 